\title{
Clinical Evidence and Mechanisms of High-Protein Diet-Induced Weight Loss
}

\author{
Jaecheol Moon', Gwanpyo Koh ${ }^{1,2, *}$ \\ ${ }^{1}$ Department of Internal Medicine, Jeju National University Hospital, Jeju; ${ }^{2}$ Department of Internal Medicine, Jeju National University School of Medicine, Jeju, Korea
}

Several clinical trials have found that consuming more protein than the recommended dietary allowance not only reduces body weight (BW), but also enhances body composition by decreasing fat mass while preserving fat-free mass (FFM) in both low-calorie and standard-calorie diets. Fairly long-term clinical trials of 6-12 months reported that a high-protein diet (HPD) provides weight-loss effects and can prevent weight regain after weight loss. HPD has not been reported to have adverse effects on health in terms of bone density or renal function in healthy adults. Among gut-derived hormones, glucagon-like peptide-1, cholecystokinin, and peptide tyrosinetyrosine reduce appetite, while ghrelin enhances appetite. HPD increases these anorexigenic hormone levels while decreasing orexigenic hormone levels, resulting in increased satiety signaling and, eventually, reduced food intake. Additionally, elevated diet-induced thermogenesis (DIT), increased blood amino acid concentration, increased hepatic gluconeogenesis, and increased ketogenesis caused by higher dietary protein contribute to increased satiety. The mechanism by which HPD increases energy expenditure involves two aspects: first, proteins have a markedly higher DIT than carbohydrates and fats. Second, protein intake prevents a decrease in FFM, which helps maintain resting energy expenditure despite weight loss. In conclusion, HPD is an effective and safe tool for weight reduction that can prevent obesity and obesity-related diseases. However, long-term clinical trials spanning more than 12 months should be conducted to further substantiate HPD effects.
Received April 1, 2020

Reviewed April 25, 2020

Accepted May 19, 2020

*Corresponding author

Gwanpyo Koh

\section{(10)}

https://orcid.org/0000-0002-6020-2777

Department of Internal Medicine, Jeju National University School of Medicine, 102 Jejudaehang-ro, Jeju 54987, Korea Tel: +82-64-754-8163

Fax: +82-64-717-1131

E-mail: okdom@jejunu.ac.kr

Key words: High protein diet, Weight loss, Obesity, Satiation

\section{INTRODUCTION}

Prevalence of obesity around the world have increased rapidly in recent years. This phenomenon poses serious health risks because obesity can progressively cause a wide range of diseases such metabolic syndrome, non-alcoholic fatty liver disease, type 2 diabetes, and cardiovascular diseases. ${ }^{1}$ To resolve obesity, a negative energy balance, in which energy expenditure is greater than energy intake, must be encouraged. This can be achieved via an energy-restricted diet. ${ }^{2}$ However, an energy-restricted diet carries the risk of post-loss weight regain because it increases hunger and decreases fullness. Furthermore, weight loss through an energy-restricted diet reduces fat mass and fat-free mass (FFM), which hinders a continuous neg- ative energy balance. To overcome this, lowering energy intake while maintaining fullness and FFM is crucial, and a high-protein, energy-restricted diet is one important strategy. ${ }^{3,4}$ In this review article, we examine the clinical evidence for the weight-loss effects and side effects of high-protein diet (HPD) and introduce various mechanisms through which HPD increases satiety and induces weight loss while preserving FFM.

\section{CLINICAL OUTCOMES WITH HPD}

Protein is a component of the human body, a source of energy, and an essential nutrient that facilitates growth and development. The recommended dietary allowance of protein to avoid protein

Copyright (C) 2020 Korean Society for the Study of Obesity

(ㄷ) This is an Open Access article distributed under the terms of the Creative Commons Attribution Non-Commercial License (https://creativecommons.org/licenses/by-nc/4.0/) which permits unrestricted non-commercial use, distribution, and reproduction in any medium, provided the original work is properly cited. 
deficiency in adults is $0.80 \mathrm{~g} / \mathrm{kg}$ body weight (BW)/day, which translates to about $48-56 \mathrm{~g} /$ day and about $10 \%-15 \%$ of the total daily energy expenditure. ${ }^{5}$ To date, many clinical trials have attempted to regulate BW through high protein consumption more than the recommended dietary allowance (Table 1).

Wycherley et al. ${ }^{4}$ conducted a meta-analysis of 24 randomized controlled trials (RCTs) that compared HPD and standard-protein diet (SPD) with isocaloric, energy-restricted diets. Subjects in the HPD group consumed 1.07-1.60 g protein/kg BW/day (27\%-35\% of total energy intake consumed as protein), and subjects in the SPD group consumed $0.55-0.88 \mathrm{~g} / \mathrm{kg} \mathrm{BW} /$ day (16\%-21\% of total energy intake consumed as protein), with the two groups having a difference less than $1,250 \mathrm{~kJ} /$ day in total energy intake. A total of 1,063 participants were enrolled, and the mean ( \pm standard deviation) diet duration was 12.1 \pm 9.3 weeks. Compared with subjects in the SPD group, those in the HPD group showed a significant reduction in BW $(-0.79 \mathrm{~kg}$; $95 \%$ confidence interval [CI], -1.50 to $-0.08 \mathrm{~kg})$, fat mass ( $-0.87 \mathrm{~kg} ; 95 \% \mathrm{CI},-1.26$ to $-0.48 \mathrm{~kg})$, and blood triglycerides ( $-20.3 \mathrm{mg} / \mathrm{dL}$; $95 \% \mathrm{CI},-29.2$ to $-10.6 \mathrm{mg} / \mathrm{dL}$ ) and a significant increase in FFM (0.43 kg; 95\% CI, 0.09-0.78 kg) and resting energy expenditure (REE; 595.5 kJ/day; 95\% CI, 67.0$1,124.1 \mathrm{~kJ} /$ day). Santesso et al. ${ }^{6}$ conducted a meta-analysis of 74 RCTs with less than 5\% difference in calorie intake between the two study groups regardless of energy restriction. Compared with subjects in the SPD group who consumed protein as 5\%-23\% of their daily total energy, subjects in the HPD group who consumed protein as $16 \%-45 \%$ of their daily total energy showed a significant decrease in BW $(-0.36 \mathrm{~kg}$; $95 \% \mathrm{CI},-0.56$ to $-0.17 \mathrm{~kg})$, body mass index $\left(-0.37 \mathrm{~kg} / \mathrm{m}^{2} ; 95 \% \mathrm{CI},-0.56\right.$ to $\left.0.19 \mathrm{~kg} / \mathrm{m}^{2}\right)$, waist circumference $(-0.43 \mathrm{~cm}$; $95 \% \mathrm{CI},-0.69$ to $-0.16 \mathrm{~cm})$, and blood pressure (systolic: $-0.21 \mathrm{mmHg}$; 95\% CI, -0.32 to $-0.09 \mathrm{mmHg}$ and diastolic: $-0.18 \mathrm{mmHg}$; $95 \% \mathrm{CI},-0.29$ to $-0.06 \mathrm{mmHg}$ ), but the degree of improvement was small.

Most clinical trials examining the effects of HPD used controlled diets, which were provided by the investigators. However, Skov et al. ${ }^{7}$ and Weigle et al. ${ }^{8}$ conducted clinical trials involving ad libitum diets. Skov et al. ${ }^{7}$ conducted a six-month randomized dietary intervention trial, where participants were divided into an HPD (protein as $25 \%$ of total energy intake, $n=25$ ), high-carbohydrate diet (protein as $12 \%$ of total energy intake, $n=25)$, or control group $(n=15)$, with fat intake set to $30 \%$ of total energy intake. Although the participants followed an ad libitum diet at designated restaurants, they were instructed to strictly adhere to the required diet composition. In contrast to other controlled feeding trials, the withdrawal rate was very low $(<10 \%)$. After 6 months, participants in the high-protein group significantly lost BW ( $-3.7 \mathrm{~kg} ; 95 \% \mathrm{CI},-6.2$ to $-1.3 \mathrm{~kg})$ and fat mass ( $-3.3 \mathrm{~kg}$; 95\% CI, -5.5 to $-1.1 \mathrm{~kg}$ ) compared with those in the high-carbohydrate diet group. Similar results were observed in the study by Weigle et al. ${ }^{8}$ That study was a single-arm trial involving a weight-maintaining diet (15\% protein, $35 \%$ fat, and $50 \%$ carbohydrate) for the first 2 weeks, an isocaloric HPD (30\% protein, $20 \%$ fat, and $50 \%$ carbohydrate) for the next 2 weeks, and an ad libitum HPD (30\% protein, 20\% fat, and 50\% carbohydrate) for

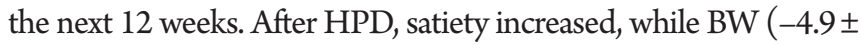
$0.5 \mathrm{~kg})$ and fat mass $(-3.7 \pm 0.4 \mathrm{~kg})$ significantly decreased.

Some studies examined the effect of HPD on weight regain after weight loss. Westerterp-Plantenga et al. ${ }^{9}$ induced weight loss through a 4-week, very low-energy diet in 148 mildly obese participants, after which protein was additionally administered at $48.2 \mathrm{~g} /$ day for 3 months. The participants in the group given additional protein consumed $18 \%$ of their daily total energy as protein, while the control group consumed $15 \%$ of their daily total energy as protein. Participants in the protein group showed 50\% less weight regain compared with control-group participants. Weight regain constituted FFM in the protein-group participants and fat mass in the controlgroup participants. Lejeune et al. ${ }^{10}$ also observed less weight regain in participants consuming $30 \mathrm{~g} /$ day of protein for 6 months ( $0.8 \mathrm{vs}$. $3.0 \mathrm{~kg} ; P<0.05)$. Clifton et al. ${ }^{11}$ and Layman et al. ${ }^{12}$ compared HPD and high-carbohydrate diet for nine and 12 months, respectively, and they confirmed a correlation between protein intake and weight loss and between protein intake and fat-mass reduction, respectively.

In conclusion, many clinical trials have shown that consuming more protein than the recommended dietary allowance induces weight loss and improves body composition regardless of total energy intake. HPD was also observed to have long-term weight-loss effects and to prevent weight regain following initial weight loss.

\section{POSSIBLE HARMFUL EFFECTS OF HPD}

The benefits of HPD are well known, but there have been con- 


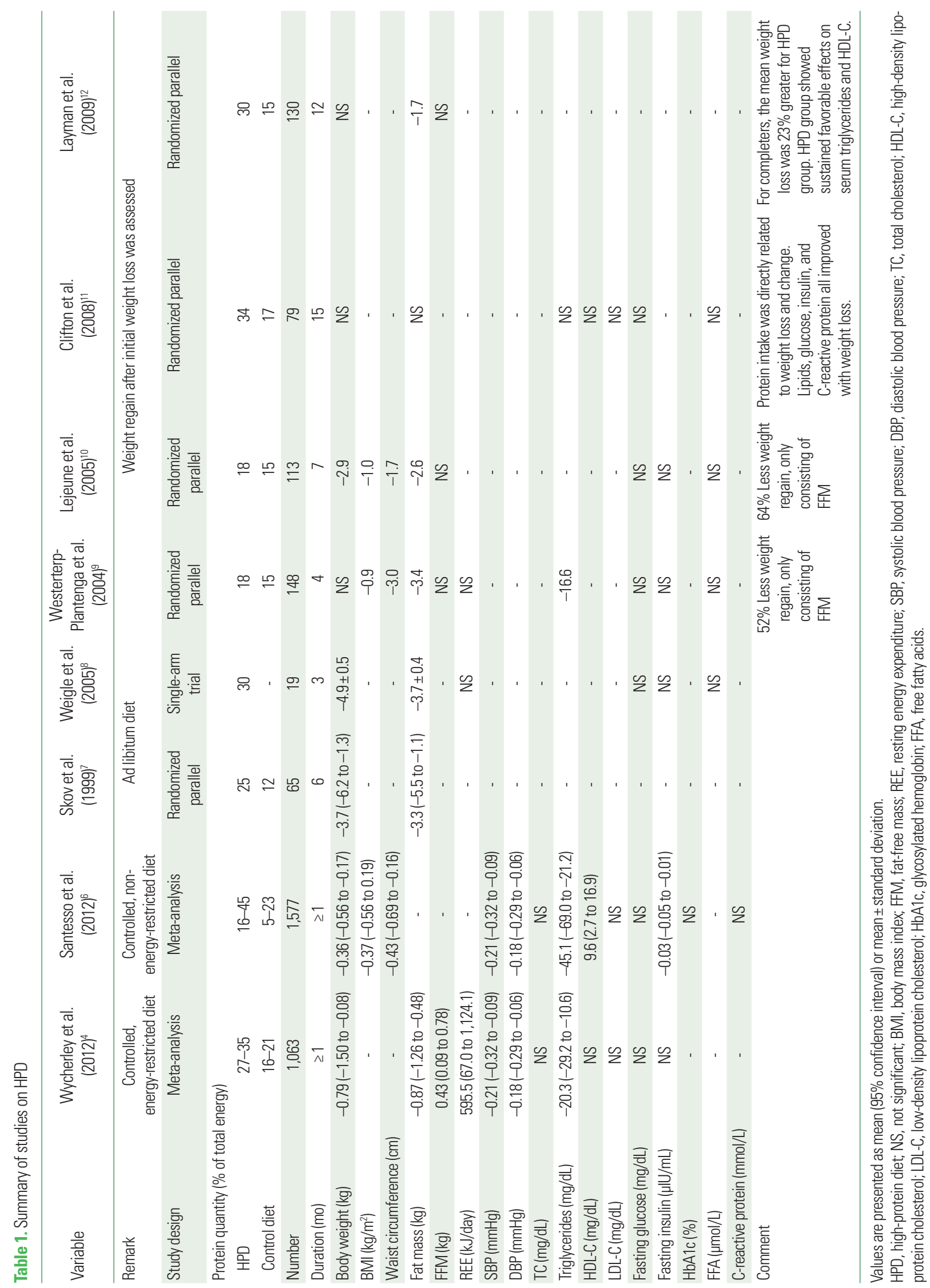


cerns that it may be harmful to the bones and kidneys. It has long been hypothesized that HPD increases the resorption of bones, which act as buffers, by increasing the acid load in the body, ${ }^{13}$ and some researchers argued that HPD increases risk for bone fracture and osteoporosis by accelerating bone resorption and urinary calcium excretion. ${ }^{14}$ However, a meta-analysis of 74 RCTs observed that subjects in the HPD group (16\%-45\% of total daily energy intake as protein) were not significantly different from low-protein-diet subjects ( $5 \%-23 \%$ of total daily energy intake as protein) with regard to bone mineral density of the lumbar spine and hips. ${ }^{6}$ Furthermore, low protein intake is generally considered a nutritional deficiency. In particular, it has been described as a factor affecting osteoporosis development in older adults. ${ }^{15}$ Hannan et al. ${ }^{16}$ reported that protein intake was negatively correlated with bone loss in their Framingham Osteoporosis Study, which prospectively examined 615 older adults over four years. There have also been concerns that HPD may deteriorate renal function by increasing the glomerular filtration rate (GFR) and inducing renal hypertrophy. However, Friedman et al. ${ }^{17}$ found no declining renal function in terms of various indicators such as GFR and albuminuria when studying the safety of HPD in 307 obese adults with normal renal function over two years (24 months). Nevertheless, they reported increased calcium level in urine with neither reduction in bone mineral density nor urolithiasis, calling for further studies. Knight et al. ${ }^{18}$ also reported no association of high protein intake with change in GFR in their prospective Nurses' Health Study, which involved 1,624 females. They noted that GFR decreased by $1.69 \mathrm{~mL} / \mathrm{min}$ per $1.73 \mathrm{~m}^{2}$ in participants with mild renal insufficiency (GFR $55-80 \mathrm{~mL} / \mathrm{min}$ / $1.73 \mathrm{~m}^{2}$ ) when protein intake was increased by $10 \mathrm{~g}$. Overall, HPD does not lead to reduced bone mineral density. On the contrary, high protein intake can help prevent bone loss in older adults who are prone to nutritional deficiency. While HPD also does not affect renal function in healthy people, it can adversely affect renal function in people with kidney disease. There is not a clear definition of the upper limit of beneficial protein intake, but Millward ${ }^{19}$ reported in their study on energy-restricted HPD that up to $1.66 \mathrm{~g} / \mathrm{kg} \mathrm{BW/}$ day does not pose a health hazard. Martens et al. ${ }^{20}$ and Bray et al. ${ }^{21}$ studied HPD with neutral or positive energy balance, and they reported that consuming an amount of protein that accounts for $25 \%-30 \%$ of the total daily energy intake for $10-12$ weeks did not induce any adverse effects. However, more long-term clinical trials are required to identify a safe upper limit of HPD.

\section{MECHANISMS OF HPD-INDUCED WEIGHT LOSS}

Dietary protein not only decreases BW by increasing satiety and energy expenditure, but also improves body composition by increasing FFM. Increased satiety from protein intake is associated with elevation of blood amino acid (AA) concentration, hunger-inhibiting hormones, diet-induced thermogenesis (DIT), and ketone body levels. While HPD induces a negative energy balance-a state of greater energy output than input-by increasing DIT and sleeping metabolic rate, low-protein diets promote a positive energy balance. ${ }^{22}$

\section{Energy expenditure}

HPD increases energy expenditure by increasing DIT and resting metabolism. Daily energy expenditure is divided into three elements: (1) sleeping metabolic rate or REE, (2) DIT or diet-induced energy expenditure, and (3) activity-induced energy expenditure. Protein intake generally affects DIT. ${ }^{2}$ DIT refers to the energy required for intestinal absorption of nutrients, early stages of nutrient metabolism, and nutrient storage. The total energy and protein percentage of a diet are the major determinants of DIT. In other words, DIT increases with increasing calories and protein content. DIT is known to be $0 \%-3 \%$ of total energy intake for fat, $5 \%-10 \%$ for carbohydrates, and $20 \%-30 \%$ for proteins. ${ }^{23}$

HPD also contributes to weight loss by preventing a decline in REE. Wycherley et al. ${ }^{4}$ performed a meta-analysis of 24 RCTs and found that, while subjects in both the HPD $(1.25 \pm 0.17 \mathrm{~g}$ protein/ $\mathrm{kg} \mathrm{BW} /$ day $)$ and SPD $(0.72 \pm 0.09 \mathrm{~g}$ protein $/ \mathrm{kg} \mathrm{BW} /$ day $)$ groups had reduced REE, REE was higher in the HPD subjects ( $142 \mathrm{kcal} /$ day, $95 \%$ CI, 16-269 kcal/day). HPD is known to preserve REE by preventing lean mass loss. ${ }^{4}$

Once DIT is increased by HPD, satiety is also increased. The increased oxygen demand required to metabolize consumed protein also increases satiety. ${ }^{24}$ In a similar mechanism, people who live at high altitudes, where oxygen pressure is low, are lighter due to lower dietary intake. ${ }^{25}$ 
In general, dietary protein increases energy expenditure because it has a markedly higher DIT than fat and carbohydrates, and it preserves REE by preventing lean mass loss. Furthermore, increased DIT increases satiety, which also contributes to weight loss.

\section{Satiety hormones}

To the best of our knowledge, Holt et al. ${ }^{26}$ were the first to show that dietary protein increases satiety. In their study, they rated satiety for 38 foods, and protein-rich food received the highest ratings, followed by carbohydrate-rich and fat-rich foods. They further reported that a food's protein content was proportional to its satiety index score, while fat content was inversely proportional to satiety index score.

One of the important mechanisms of HPD-induced satiety involves elevation of the anorexigenic hormones glucagon-like peptide-1 (GLP-1), cholecystokinin (CCK), and peptide tyrosine-tyrosine (PYY). ${ }^{27,28}$ Release of GLP-1, CCK, and PYY is stimulated by proteins that also stimulate the vagus nerve, thus reducing food intake. ${ }^{29}$ The enteroendocrine cells that secrete these anorexigenic hormones are situated at the luminal side of the gut. These cells detect nutrients in the gastrointestinal tract and release GLP-1, PYY, and CCK, which increase satiety and decrease food intake. ${ }^{30,31}$ Many clinical trials that compared the effects of HPD and SPD on the indices of appetite regulation and satiety found that HPD increased plasma PYY, GLP-1, and CCK levels, with a proportional increase in fullness and decrease in hunger sense. ${ }^{32,33}$

Ghrelin is an orexigenic hormone that induces food intake by increasing hunger, and its plasma concentration is decreased by protein intake. ${ }^{34}$ Bowen et al..$^{35,36}$ found that liquid preloads containing protein rather than glucose significantly suppressed ghrelin release. In conclusion, dietary protein elevates GLP-1, CCK, and PYY levels, which are secreted in the gut and diminish appetite while also decreasing ghrelin levels, which increases appetite. Such changes in the release of satiety hormones constitute an important mechanism of HPD-induced weight loss.

\section{Aminostatic hypothesis}

The aminostatic hypothesis, which proposes that elevated levels of plasma AAs increase satiety and, conversely, decrease the plasma AA that induces hunger, was first introduced in $1956 .{ }^{37}$ According to this hypothesis, surplus AAs not involved in the body's protein synthesis stimulate the brain's satiety signaling. Multiple studies reported that HPDs significantly increased plasma AA concentration $^{38}$ and satiety ${ }^{24,39}$ compared with high-fat or high-carbohydrate diets. However, the aminostatic theory has recently lost support because fasting plasma AA levels are not associated with appetite, and increased plasma AA concentration following protein intake is not consistently associated with appetite. ${ }^{40}$ Future studies should more specifically examine the homeostatic mechanism that connects peripheral organs to the central nervous system, which might explain the aminostatic hypothesis.

\section{Gluconeogensis}

Increased gluconeogenesis due to dietary protein is another mechanism of HPD-induced weight loss. With HPD, AAs remaining after protein synthesis are involved in an alternative pathway known as gluconeogenesis. ${ }^{41}$ HPD increases the expression of phosphoenolpyruvate carboxykinase, an enzyme that initiates gluconeogenesis, and glucose-6-phosphatase, an enzyme involved in the final stages of gluconeogenesis. As such, the increased energy usage in gluconeogenesis increases energy expenditure, contributing to weight loss. ${ }^{42}$ Furthermore, the elevation of glucose as a result of gluconeogenesis and the subsequent elevation of hepatic glycogen synthesis because of increased glucose level are known to intensify the sense of satiety in the brain. ${ }^{42,43}$

\section{Ketogenesis}

Compared to a standard diet, high-protein and low-carbohydrate diets increase fasting blood $\beta$-hydroxybutyrate concentration. Elevated $\beta$-hydroxybutyrate concentration is known to directly increase satiety. ${ }^{44}$ Veldhorst et al..$^{45}$ reported that, although carbohydrate-free HPD increased gluconeogenesis, the mechanism did not involve appetite; rather, they speculated that the elevated $\beta$-hydroxybutyrate level triggered satiety. On the other hand, some argue that HPD does not suppress appetite, but only prevents an appetite increase. In other words, one's appetite remains the same with both energyrestricted HPD and the standard-energy medium-protein diet, but the high-protein content in HPD contributes to weight loss by preventing excessive food intake at the next meal even if the total energy intake was low. ${ }^{20,46}$ 


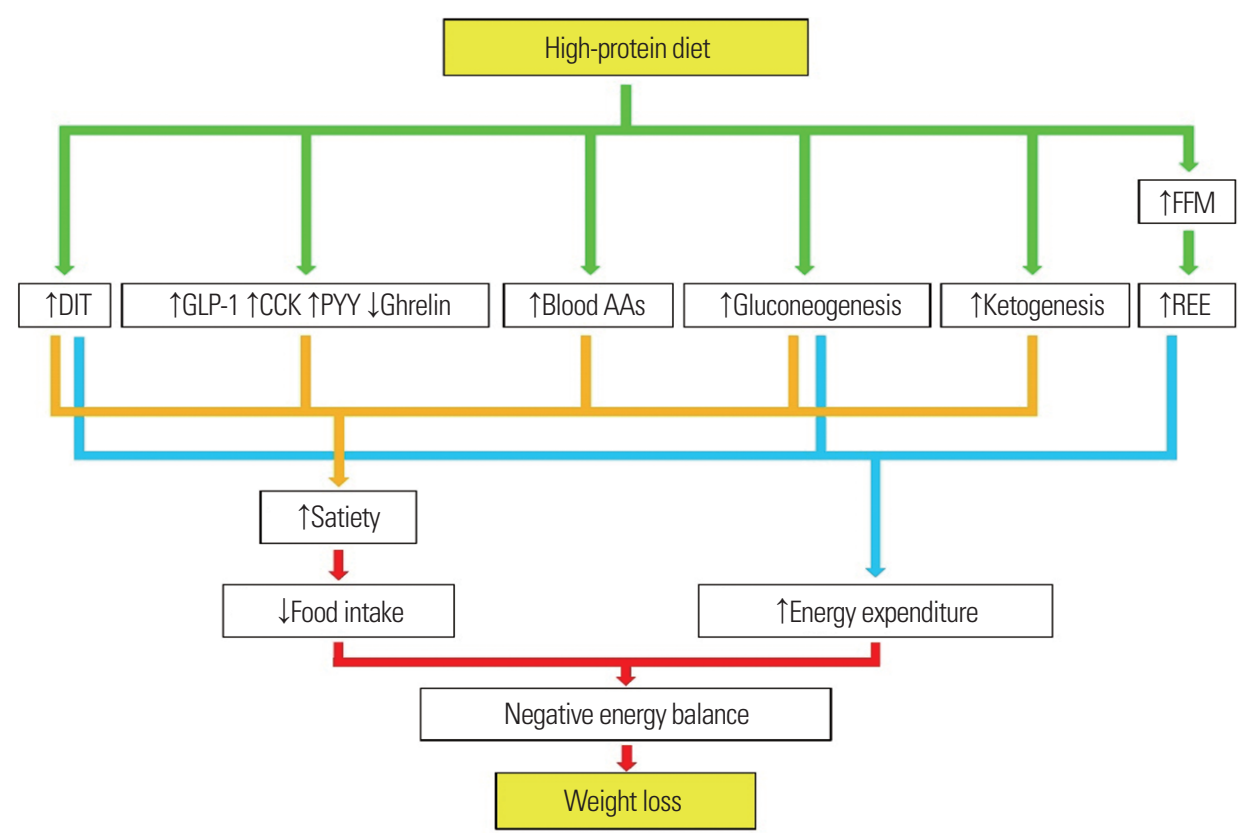

Figure 1. Schematic of the proposed high-protein diet-induced weight loss mechanism. $\uparrow$, increase; $\downarrow$, decrease; FFM, fat-free mass; DIT, diet-induced thermogenesis; GLP-1, glucagon-like peptide-1; CCK, cholecystokinin; PYY, peptide tyrosine-tyrosine; AA, amino acid; REE, resting energy expenditure.

\section{CONCLUSION}

Clinical trials with various designs have found that HPD induces weight loss and lowers cardiovascular disease risk factors such as blood triglycerides and blood pressure while preserving FFM. Such weight-loss effects of protein were observed in both energyrestricted and standard-energy diets and in long-term clinical trials with follow-up durations of 6-12 months. Contrary to some concerns, there is no evidence that HPD is harmful to the bones or kidneys. However, longer clinical trials that span more than one year are required to examine the effects and safety of HPD in more depth.

The mechanism underlying HPD-induced weight loss involves an increase in satiety and energy expenditure. Increased satiety is believed to be a result of elevated levels of anorexigenic hormones, decreased levels of orexigenic hormones, increased DIT, elevated plasma AA levels, increased hepatic gluconeogenesis, and increased ketogenesis from the higher protein intake. Protein is known to increase energy expenditure by having a markedly higher DIT than carbohydrates and fat, and increasing protein intake preserves REE by preventing FFM decrease (Fig. 1).

In conclusion, HPD is a safe method for losing weight while pre- serving FFM; it is thought to also prevent obesity and obesity-related diseases, such as metabolic syndrome, non-alcoholic fatty liver disease, type 2 diabetes, and cardiovascular diseases.

\section{CONFLICTS OF INTEREST}

The authors declare no conflict of interest.

\section{ACKNOWLEDGMENTS}

This work was supported by the 2020 education, research, and student guidance grant, funded by Jeju National University.

\section{AUTHOR CONTRIBUTIONS}

Study concept and design: GK; acquisition of data: all authors; analysis and interpretation of data: all authors; drafting of the manuscript: JM; critical revision of the manuscript: GK; obtained funding: GK; administrative, technical, or material support: GK; and study supervision: GK. 


\section{REFERENCES}

1. World Health Organization. Obesity and overweight 2020 [Internet]. Geneva: World Health Organization; 2020 [cited 2020 Jul 5]. Available from: https://www.who.int/en/news-room/ fact-sheets/detail/obesity-and-overweight

2. Westerterp-Plantenga MS, Nieuwenhuizen A, Tomé D, Soenen S, Westerterp KR. Dietary protein, weight loss, and weight maintenance. Annu Rev Nutr 2009;29:21-41.

3. Acheson KJ. Diets for body weight control and health: the potential of changing the macronutrient composition. Eur J Clin Nutr 2013;67:462-6.

4. Wycherley TP, Moran LJ, Clifton PM, Noakes M, Brinkworth GD. Effects of energy-restricted high-protein, low-fat compared with standard-protein, low-fat diets: a meta-analysis of randomized controlled trials. Am J Clin Nutr 2012;96:1281-98.

5. Fulgoni VL 3rd. Current protein intake in America: analysis of the National Health and Nutrition Examination Survey, 20032004. Am J Clin Nutr 2008;87:1554S-1557S.

6. Santesso N, Akl EA, Bianchi M, Mente A, Mustafa R, HeelsAnsdell D, et al. Effects of higher- versus lower-protein diets on health outcomes: a systematic review and meta-analysis. Eur J Clin Nutr 2012;66:780-8.

7. Skov AR, Toubro S, Rønn B, Holm L, Astrup A. Randomized trial on protein vs carbohydrate in ad libitum fat reduced diet for the treatment of obesity. Int J Obes Relat Metab Disord 1999;23:528-36.

8. Weigle DS, Breen PA, Matthys CC, Callahan HS, Meeuws KE, Burden VR, et al. A high-protein diet induces sustained reductions in appetite, ad libitum caloric intake, and body weight despite compensatory changes in diurnal plasma leptin and ghrelin concentrations. Am J Clin Nutr 2005;82:41-8.

9. Westerterp-Plantenga MS, Lejeune MP, Nijs I, van Ooijen M, Kovacs EM. High protein intake sustains weight maintenance after body weight loss in humans. Int J Obes Relat Metab Disord 2004;28:57-64.

10. Lejeune MP, Kovacs EM, Westerterp-Plantenga MS. Additional protein intake limits weight regain after weight loss in humans. Br J Nutr 2005;93:281-9.

11. Clifton PM, Keogh JB, Noakes M. Long-term effects of a high- protein weight-loss diet. Am J Clin Nutr 2008;87:23-9.

12. Layman DK, Evans EM, Erickson D, Seyler J, Weber J, Bagshaw D, et al. A moderate-protein diet produces sustained weight loss and long-term changes in body composition and blood lipids in obese adults. J Nutr 2009;139:514-21.

13. Calvez J, Poupin N, Chesneau C, Lassale C, Tomé D. Protein intake, calcium balance and health consequences. Eur J Clin Nutr 2012;66:281-95.

14. Heaney RP, Layman DK. Amount and type of protein influences bone health. Am J Clin Nutr 2008;87:1567S-1570S.

15. Bonjour JP, Schurch MA, Rizzoli R. Nutritional aspects of hip fractures. Bone 1996;18(3 Suppl):139S-144S.

16. Hannan MT, Tucker KL, Dawson-Hughes B, Cupples LA, Felson DT, Kiel DP. Effect of dietary protein on bone loss in elderly men and women: the Framingham Osteoporosis Study. J Bone Miner Res 2000;15:2504-12.

17. Friedman AN, Ogden LG, Foster GD, Klein S, Stein R, Miller B, et al. Comparative effects of low-carbohydrate high-protein versus low-fat diets on the kidney. Clin J Am Soc Nephrol 2012; 7:1103-11.

18. Knight EL, Stampfer MJ, Hankinson SE, Spiegelman D, Curhan GC. The impact of protein intake on renal function decline in women with normal renal function or mild renal insufficiency. Ann Intern Med 2003;138:460-7.

19. Millward DJ. Identifying recommended dietary allowances for protein and amino acids: a critique of the $2007 \mathrm{WHO} / \mathrm{FAO} /$ UNU report. Br J Nutr 2012;108 Suppl 2:S3-21.

20. Martens EA, Tan SY, Dunlop MV, Mattes RD, Westerterp-Plantenga MS. Protein leverage effects of beef protein on energy intake in humans. Am J Clin Nutr 2014;99:1397-406.

21. Bray GA, Smith SR, de Jonge L, Xie H, Rood J, Martin CK, et al. Effect of dietary protein content on weight gain, energy expenditure, and body composition during overeating: a randomized controlled trial. JAMA 2012;307:47-55.

22. Drummen M, Tischmann L, Gatta-Cherifi B, Adam T, Westerterp-Plantenga M. Dietary protein and energy balance in relation to obesity and co-morbidities. Front Endocrinol (Lausanne) 2018;9:443.

23. Tappy L. Thermic effect of food and sympathetic nervous system activity in humans. Reprod Nutr Dev 1996;36:391-7. 
24. Westerterp-Plantenga MS, Rolland V, Wilson SA, Westerterp KR. Satiety related to $24 \mathrm{~h}$ diet-induced thermogenesis during high protein/carbohydrate vs high fat diets measured in a respiration chamber. Eur J Clin Nutr 1999;53:495-502.

25. Lippl FJ, Neubauer S, Schipfer S, Lichter N, Tufman A, Otto B, et al. Hypobaric hypoxia causes body weight reduction in obese subjects. Obesity (Silver Spring) 2010;18:675-81.

26. Holt SH, Miller JC, Petocz P, Farmakalidis E. A satiety index of common foods. Eur J Clin Nutr 1995;49:675-90.

27. Belza A, Ritz C, Sørensen MQ Holst JJ, Rehfeld JF, Astrup A. Contribution of gastroenteropancreatic appetite hormones to protein-induced satiety. Am J Clin Nutr 2013;97:980-9.

28. Diepvens K, Häberer D, Westerterp-Plantenga M. Different proteins and biopeptides differently affect satiety and anorexigenic/orexigenic hormones in healthy humans. Int J Obes (Lond) 2008;32:510-8.

29. Davidenko O, Darcel N, Fromentin G, Tomé D. Control of protein and energy intake: brain mechanisms. Eur J Clin Nutr 2013;67:455-61.

30. Koh G. Gut hormone response to diet. Korean J Obes 2014; 23:6-15.

31. Tan T, Bloom S. Gut hormones as therapeutic agents in treatment of diabetes and obesity. Curr Opin Pharmacol 2013;13: 996-1001.

32. Halton TL, Hu FB. The effects of high protein diets on thermogenesis, satiety and weight loss: a critical review. J Am Coll Nutr 2004;23:373-85.

33. van der Klaauw AA, Keogh JM, Henning E, Trowse VM, Dhillo WS, Ghatei MA, et al. High protein intake stimulates postprandial GLP1 and PYY release. Obesity (Silver Spring) 2013;21: 1602-7.

34. Wren AM, Seal LJ, Cohen MA, Brynes AE, Frost GS, Murphy $\mathrm{KG}$, et al. Ghrelin enhances appetite and increases food intake in humans. J Clin Endocrinol Metab 2001;86:5992.

35. Bowen J, Noakes M, Clifton PM. Appetite regulatory hormone responses to various dietary proteins differ by body mass index status despite similar reductions in ad libitum energy intake. J Clin Endocrinol Metab 2006;91:2913-9.

36. Bowen J, Noakes M, Trenerry C, Clifton PM. Energy intake, ghrelin, and cholecystokinin after different carbohydrate and protein preloads in overweight men. J Clin Endocrinol Metab 2006;91:1477-83.

37. Mellinkoff SM, Frankland M, Boyle D, Greipel M. Relationship between serum amino acid concentration and fluctuations in appetite. J Appl Physiol 1956;8:535-8.

38. Veldhorst MA, Nieuwenhuizen AG, Hochstenbach-Waelen A, Westerterp KR, Engelen MP, Brummer RJ, et al. Comparison of the effects of a high- and normal-casein breakfast on satiety, 'satiety' hormones, plasma amino acids and subsequent energy intake. Br J Nutr 2009; 101:295-303.

39. Poppitt SD, McCormack D, Buffenstein R. Short-term effects of macronutrient preloads on appetite and energy intake in lean women. Physiol Behav 1998;64:279-85.

40. Niijima A, Torii K, Uneyama H. Role played by vagal chemical sensors in the hepato-portal region and duodeno-intestinal canal: an electrophysiological study. Chem Senses 2005;30 Suppl 1:i178-9.

41.Jungas RL, Halperin ML, Brosnan JT. Quantitative analysis of amino acid oxidation and related gluconeogenesis in humans. Physiol Rev 1992;72:419-48.

42. Azzout-Marniche D, Gaudichon C, Blouet C, Bos C, Mathé V, Huneau JF, et al. Liver glyconeogenesis: a pathway to cope with postprandial amino acid excess in high-protein fed rats? Am J Physiol Regul Integr Comp Physiol 2007;292:R1400-7.

43. McCarty MF. Promotion of hepatic lipid oxidation and gluconeogenesis as a strategy for appetite control. Med Hypotheses 1994;42:215-25.

44. Veldhorst MA, Westerterp KR, van Vught AJ, Westerterp-Plantenga MS. Presence or absence of carbohydrates and the proportion of fat in a high-protein diet affect appetite suppression but not energy expenditure in normal-weight human subjects fed in energy balance. Br J Nutr 2010;104:1395-405.

45. Veldhorst MA, Westerterp KR, Westerterp-Plantenga MS. Gluconeogenesis and protein-induced satiety. Br J Nutr 2012;107: 595-600.

46. Martens EA, Lemmens SG, Westerterp-Plantenga MS. Protein leverage affects energy intake of high-protein diets in humans. Am J Clin Nutr 2013;97:86-93. 